\title{
Representações da violência intrafamiliar por idosas e idosos
}

\author{
Vicente de Paula Faleiros* \\ Denise Orbage de Brito*
}

Resumo: Apresentamos os resultados de uma pesquisa qualitativa com pessoas idosas, fundamentada na teoria das representações sociais e no conceito relacional de violência como poder desigual. Usamos o método da entrevista semi-estruturada. A violência intrafamiliar não está separada da violência social, pois implica relações complexas e diversas com os processos e a estrutura social do desemprego, do crime, do uso de drogas. As representações sociais dos maus-tratos na família tanto estão ancoradas na visão dominante de família como um lócus de união e de reciprocidade, mas quando a relação de violência se torna insuportável e transborda os limites da tolerância, como a ameaça de morte, ela é denunciada com muito sofrimento e medo.

Palavras-chave: idosos, violência, família, representações.

Representations of family violence against elderly people

Abstract: This article presents a research with elderly people in Brasilia. The research is based upon the theory of social representation and the violence theory as an inequality of power

Assistente social, PhD em Sociologia, professor da Universidade Católica de Brasília (UCB) e pesquisador do Conselho Nacional de Desenvolvimento Científico e Tecnológico (CNPq) e da Universidade de Brasília (UnB). Coordenador do Centro de Referência, Estudos e Ações sobre Crianças e Adolescentes (Cecria). Consultor e autor.

* Psicóloga, mestre em Gerontologia pela UCB. 
relation. Semi-structured interviews were used. The results show a relation between social and family violence and that the notification of abuse, when unbearable, is a moment of great suffering for the elderly. The family is represented as a locus of peace and bonding.

Keywords: the elderly, violence, family, representations.

Este artigo tem por objetivo analisar os resultados de uma pesquisa com oito idosos vítimas de violência, para aprofundar o significado que os entrevistados dão à violência ou maus-tratos familiares. A pesquisa faz parte do Grupo Geracionalidade-Imaginário-Violência (Gevim), e contou com apoio do CNPq. Realizada em 2006, foi aprovada no Comitê de Ética da Universidade Católica de Brasília, conforme o Ofício no 74/2006. Num primeiro momento fazemos referência ao conceito de representações sociais para, em seguida, abordar o conceito de violência e os resultados da pesquisa.

\section{Representações sociais}

Como fundamento teórico deste trabalho, referimo-nos, ainda que brevemente, às teorias da representação social e da violência. Conforme a Teoria e o Método das Representações Sociais, para Moscovici (1961, p. 58), representar uma coisa, um estado, consiste em "organizar, unir e filtrar o que vai ser re-introduzido e re-aprendido no domínio sensorial..., tornando familiar aquilo que é insólito, mudando o universo sem que deixe de ser o nosso universo".

Essa reconstituição se faz diversificadamente, pois grupos sociais específicos se comunicam e compartilham experiências próprias. Na perspectiva de Jodelet, a representação pode ser vista, por um lado, como um produto social de uma realidade exterior que se consolida por meio de informações, imagens, 
opiniões, valores, atitudes em relação a um determinado objeto. Por outro lado, ela é um processo, uma atividade de apropriação da realidade e de elaboração psicológica e social dessa realidade. Assim, a representação é, ao mesmo tempo, produto social de uma realidade exterior e representação social de um sujeito (indivíduo, grupo, família, classe). Para Jodelet (2001, p. 22), as representações sociais são uma forma de conhecimento socialmente elaborado e compartilhado, com um objetivo prático, e que contribui para a construção de uma realidade comum a um conjunto social. Sperber (2001, p. 90) destaca que as representações mentais podem ser uma lembrança, uma hipótese ou uma intenção, como acontece com pessoas idosas. Ao longo do texto vamos referir constantemente à objetivação e à ancoragem das representações sociais. Segundo Jodelet, a primeira é uma seleção de conteúdos vinculados à pertença social dos sujeitos que se esquematiza e naturaliza na comunicação. A ancoragem torna a objetivação concreta, instrumental, por meio de imagens. As expressões dos colaboradores da pesquisa, assim, são expressões de vínculos de seu mundo pessoal ao mundo social, da sociedade e da família onde se relacionam. A violência é representada nessas relações.

\section{Violência}

A violência (os maus-tratos) é entendida, segundo Faleiros $(2004,2007)$, como um processo social relacional complexo e diverso, diferentemente de uma visão de desvio ou anomia (Merton, 1970). A violência se inscreve num processo relacional e de poder, na perspectiva de Hanna Arendt (1985), na estruturação da própria sociedade e das relações interpessoais, institucionais e familiares. A sociedade se estrutura nas relações de acumulação econômica e de poder, nas contradições entre grupos e classes dominantes 
e dominados bem como por poderes de sexo, gênero, etnias, simbólicos, culturais, institucionais, profissionais e afetivos. Nessa visão relacional, a sociedade se organiza como relação contraditória de interesses, valores, estratégias e poder fundada na divisão de classes sociais e nos processos de dominação e exploração.

Os conflitos, no entanto, não se resumem a uma simplificação genérica na luta de classes ou lutas entre potências ou mesmo na oposição entre Estado e sociedade. A conflitualidade é fundante da existência social, na esfera da dinâmica social e familiar e mesmo da existência do sujeito, dividido entre o desejo e as normas sociais de proibição da realização do desejo. A partir de uma visão conflituosa (Braud, 2004) da sociedade, as relações entre grupos e pessoas implicam disputa por posições, domínios, vantagens, lugares, numa estrutura complexa que garanta poderes reais ou simbólicos a determinados indivíduos ou grupos em detrimento de outros. Na realidade, o conflito social de interesses, valores, saber e poder se inscreve tanto no âmbito macrossocial como nas relações de "mascaramento ou bloqueamento de saberes locais e marginais e também pela imposição do silêncio, do segredo e de dispositivos e de mecanismos que se exercem em níveis diferentes e domínios e extensões variadas, sem se reduzir à economia" (Foucault, 1979, p. 175).

A violência, pois, expressa uma relação de poder e de força. A força do poder implica assegurar o lugar de mais forte, com a submissão do outro por meio de estratégias, mecanismos, dispositivos, arranjos que levem o outro a se curvar e mesmo a consentir ao dominante, com contragosto mais ou menos expresso ou escondido. Nas relações intergeracionais, o lugar da pessoa idosa resulta de uma história de vida articulada ao contexto mais geral da sociedade 
em que o poder se desenha de forma diferente ao longo dos processos sociais e familiares.

Os agressores dos idosos são na maioria filhos e filhas conforme constata Faleiros (2007); assim, nas ocorrências pesquisadas, $54,7 \%$ dos agressores da violência intrafamiliar são filhos e filhas. As mulheres são, em maior proporção, as vítimas dessa violência, configurando em média $61 \%$ das constatações de ocorrências. Os homens se destacam como maioria das vítimas em apenas sete capitais, sendo cinco da Região Norte e duas da Região Centro-Oeste (Campo Grande e Goiânia).

O impacto da violência, por sua vez, se traduz, tanto na reprodução da desigualdade, das assimetrias e dessimetrias, como na negação do conflito e do outro, no sofrimento, angústia e, também, em prejuízos ou danos para as vítimas. A violência intrafamiliar se articula com a violência social, mas nosso foco de análise vai ser o discurso das pessoas idosas na sua significação ou re-significação do ato violento praticado pelas pessoas mais próximas.

$\mathrm{Na}$ atual coorte de idosos, as famílias passaram por processos de migração, trabalho e inclusão em certos direitos sociais próprios da sociedade brasileira no seu todo (Faleiros, 2007b). No entanto, a violência ou maus-tratos estão manifestos por meio da expressão do sofrimento de cada vítima.

Assim, a violência diversa e complexa implica relações desiguais de poder e de condições sociais que negam a vida, a autoridade legítima e a diferença, destroem a tolerância, transgridem o pacto social ou legal de convivência, violando direitos e negando-se o outro. A construção de uma relação mediada pelos conflitos implica prejuízos materiais, morais ou de imagem/imaginário ou a morte do outro, em função de 
aumento de vantagens para si ou de manutenção de uma estrutura de desigualdade (Faleiros, 2004).

Nas relações de violência contra a pessoa idosa, a maior vitimização é de mulheres, pois essa violência se estrutura no machismo, numa dinâmica dominação de gênero, e se expressa nas relações de poder, tanto no imaginário como nas práticas sociais, de forma complexa, presente nas empresas, na família, no Estado e na sociedade.

\section{A família}

Nosso pressuposto é de que a família se constitui num processo relacional conjugal, intergeracional e social (Singly, 2007). A família socialmente legitimada pressupõe o reconhecimento comprometido e compromissado do outro, laços de parentesco ou afetivos, numa relação de troca de proteção e convívio, com desdobramentos na socialização dos sujeitos e nas heranças culturais, interpessoais e de bens materiais. Osório (1996) destaca as relações de aliança (casal), de filiação e de consangüinidade existentes na família. Sarti (2005) destaca que a família tem uma história que se transmite ao longo das gerações, mas, como assinala Rudinesco (2003), numa permanente reinvenção. Hoje a família de idosos depende da transição demográfica e social com pessoas longevas convivendo com duas ou mais gerações, num contexto de desemprego estrutural, de emergência do modo tecnológico de ver e de viver e de novos arranjos familiares.

$\mathrm{Na}$ dinâmica familiar os conflitos sociais fazem-se presentes, e neles se manifestam tanto relações de afeto e poder compartilhados como os desafetos, o poder autoritário e violência. Viver em família não é pré-condição de uma existência de paz. A seguir, algumas indicações da metodologia da pesquisa, nos limites deste artigo. 


\section{Metodologia de pesquisa}

Procedimentos de coleta de dados

A pesquisa foi realizada no âmbito do Distrito Federal. Os idosos participantes residem em três cidades do DF, a saber: Plano Piloto, Ceilândia e Núcleo Bandeirante. As entrevistas ocorreram sempre nas residências dos idosos em horários por eles determinados. Foram realizados três encontros com cada idoso, cada um tendo a duração de 1 hora e 50 minutos em média. A amostra partiu dos dados disponíveis na Gerência de Valorização do Idoso, com contato com as vítimas para saber se poderiam participar da pesquisa. Dez por cento apenas das pessoas contatadas se dispuseram a participar da pesquisa.

Os dados foram submetidos a análise de conteúdo, de acordo com o método de Laurence Bardin (2004, p. 36), que considera a análise de conteúdo como a melhor forma de se compreender as comunicações do ser humano, além dos significados imediatos. Para Bauer (2005), a análise de conteúdo é uma construção social que considera uma realidade no sentido de produzir inferências de um texto focal para seu contexto social de maneira objetivada. No item seguinte apresentamos o perfil dos participantes da pesquisa.

\section{Perfil dos idosos participantes da pesquisa}

O grupo de idosos foi composto por seis mulheres e dois homens. A faixa etária está compreendida dos 62 aos 80 anos, sendo: um ( $12,5 \%)$ de 60 a 65 anos, três de 66 a 69 (37,5\%), dois de 70 a $75(25 \%)$ e dois de 76 a $80(25 \%)$. A população estudada foi constituída de seis mulheres e dois homens, o que reflete a realidade do banco de dados de denúncias: cerca de $60 \%$ das denúncias registradas na Gerência de Valorização do Idoso tinham como vítimas mulheres e $39 \%$ homens, e, ainda, 
para $1 \%$ não foi possível identificar o gênero, conforme também constatado por Faleiros (2007). O grupo está constituído de cinco idosos casados, dois separados e uma viúva. Todos têm filhos e netos; três deles têm bisnetos. Deste grupo de sujeitos, cinco são nascidos na Região Nordeste e três na Sudeste. Todos optaram por viver em Brasília por acreditarem encontrar aqui melhores condições de vida.

Todos os idosos participantes da pesquisa são responsáveis por seus domicílios e seus vitimizadores dependiam economicamente deles, direta ou indiretamente. Vale a pena ressaltar que todos os idosos desta pesquisa são os provedores dos seus lares. Essa falta de perspectiva, aliada à dependência econômica pode ser considerada como fator de risco para a ocorrência dos maus-tratos (Tortosa, 2004, p. 47). Esses dados se confirmam em nosso estudo, em que, dos oito idosos participantes, a renda do idoso era a única na manutenção da família. Com relação à moradia, dos oito, sete vivem em casa própria e apenas um vive em residência alugada. No caso de residência própria, os proprietários são os idosos. Habitam na residência desses idosos de duas a quatro gerações. Dados do IBGE demonstram que, em dois mil lares de idosos, cerca de 58,7\% têm filhos morando juntos e $8,9 \%$ têm netos. Dois idosos, apesar de serem chefes de suas famílias, recebem ajuda de filhos que não vivem com eles. A ajuda é geralmente para medicamentos e serviços de saúde.

Os dados de escolaridade demonstram que seis dos oito idosos cursaram o ensino fundamental incompleto, um encontra-se em processo de alfabetização e um com graduação incompleta. A renda do grupo é diversificada, variando desde menos de um salário mínimo a mais de 30 . Dos oito participantes, três exercem algum tipo de atividade informal para complementar a renda, apenas uma idosa recebe o beneficio da previdência social e uma não tem rendimentos, 
mas administra a renda do cônjuge que se encontra debilitado fisicamente em virtude de um derrame. Quanto à autonomia e independência, os idosos da pesquisa apresentavam-nas preservadas, alguns com comprometimentos de ordem física e emocional. No que se refere à saúde física, foram mencionados hipertensão, diabetes, dores na coluna e problemas do coração. Os medicamentos para essas enfermidades são adquiridos pelo próprio idoso ou então nos postos da rede de saúde do governo. Os idosos fazem muitas críticas a esse atendimento que nem sempre supre as necessidades. Dois dos participantes relataram que, dado o alto custo dos medicamentos, quando não os encontram na farmácia do governo, recorrem aos filhos para adquiri-los.

Os participantes da pesquisa freqüentam igrejas, casa de amigos e fazem as compras em supermercados, o que é considerado por eles uma maneira de passar o tempo e de entretenimento. No grupo encontramos dois idosos que, no momento, não participavam de atividades: um deles em decorrência do processo de depressão que está vivendo, e a outra devido à recuperação de uma intervenção cirúrgica no coração. No que diz respeito à religiosidade, o grupo se apresenta bem heterogêneo. Há católicos, evangélicos e espíritas.

\section{A violência intrafamiliar contra a pessoa idosa: relação com os agressores}

Nesse contexto diversificado socialmente não existe um modelo de família, mas relações familiares que foram construídas e "inventadas", conforme nosso referencial teórico acima exposto, considerando que a violência se produz nessa relação intergeracional. 
Segundo a pesquisa, os filhos homens são os principais vitimizadores dos idosos na família, seguidos pelas filhas, genros, noras e, finalmente, pelos netos. Assim: três são filhos $(37,5 \%)$, uma é filha $(12,5 \%)$, uma é nora $(12,5 \%)$, dois são genros (25\%) e um é neto (12,5\%). Dois têm idade de 18 a 28 anos, três de 29 a 39 e três de 40 a 45 . Quanto à faixa etária dos vitimizadores, percebe-se que ela compreende as idades entre 29 e 45 anos, e o que está de acordo com a literatura sobre o tema, que indica a idade dos agressores não superior a 49 anos.

Às condições de desemprego somam-se a situação de precariedade das condições de vida e a impossibilidade de traçar projetos em longo prazo, condições essas que podem gerar a insatisfação e a procura de refúgio na bebida e nas drogas, ou mesmo a atitude agressiva como forma de expressar sua insatisfação. Nesse contexto, o sujeito mais frágil no cenário familiar é percebido como o "bode expiatório", para quem as insatisfações são dirigidas em forma de maus-tratos. Negar ao cidadão o direito de possuir uma casa, de ter trabalho e acesso à saúde, é negar-lhe o direito à vida na sociedade. Nessas circunstâncias, o sujeito passa a sentir-se um corpo estranho no cenário social, sendo atingido na sua existência enquanto ser social, já que para ele viver é, sobretudo, lutar com suas próprias forças para sobreviver. Assim, como assinalou Faleiros (2007) a violência familiar se processa em articulação com a violência social.

O contexto sociopolítico e econômico funciona como um processo que agride o modelo de família e atinge a identidade pessoal e familiar, provocando desagregações, desajustes e desequilíbrios. Com relação à escolaridade, só um dos agressores chegou a concluir o ensino superior; $50 \%$ têm ensino fundamental incompleto, $37,5 \%$ ensino médio e $12,5 \%$ ensino superior. 
A relação entre vitimizador e idoso se faz pela dependência econômica, já que, na ocasião da perpetração de maus-tratos, todos eram desempregados. Atualmente dois desses sujeitos estão em empregos fixos. $O$ ingresso no mercado de trabalho se deu após a saída do vitimizador da casa do idoso a pedido da justiça. Tanto Minayo (2003, p. 235) como Finkelhor et al. (1979) consideram a dependência econômica como um fator de risco de violência. O Quadro 1 apresenta os fatores de risco considerados pelos idosos da pesquisa, baseados em suas vivência particulares. Alertamos que os nomes dos sujeitos são fictícios de maneira a resguardar sua identidade evitando que sejam reconhecidos.

Os fatores de risco são o desemprego, a dependência econômica e a convivência do agressor com o idoso na mesma casa, além de, na maioria das situações, uso de drogas ilícitas por parte dos agressores. A relação intrafamiliar se articula às relações sociais. A família não está separada da sociedade, a família sobrevive e vive em condições sociais determinadas de produção, cultura, distribuição de riqueza e de acesso a oportunidades e políticas. Assim, a violência intrafamiliar é um processo complexo de interseção e combinação de dinâmicas e da estrutura familiar com a dinâmica e a estrutura social, haja vista, por exemplo, a violência social do tráfico, do consumismo e da discriminação presentes nas relações familiares. A questão de uma teoria da violência se coloca de forma complexa, relacional, articulando-se o familiar e o socialmente estruturado nas relações (Faleiros, 2007). Essa estruturação é expressa nas representações tanto da família de origem como da família construída. 


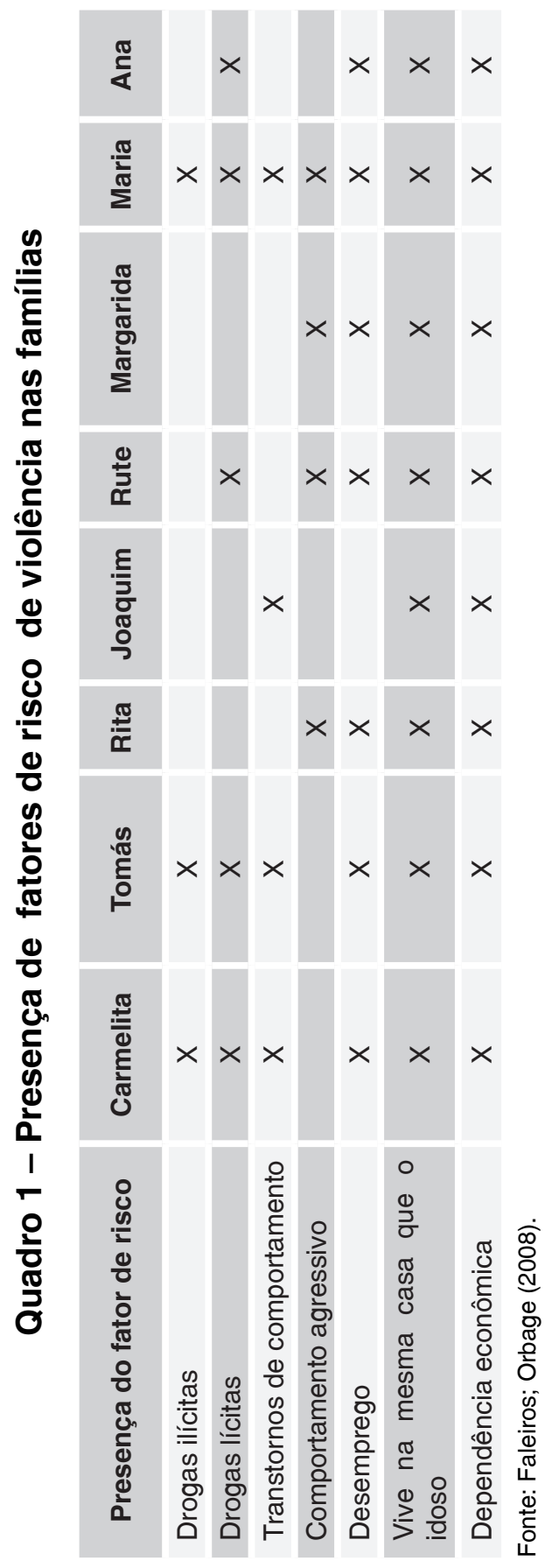




\section{As representações da família de origem dos idosos: afeto e violência}

Num primeiro momento, buscamos recolher as representações que os idosos têm da família de origem. Cada um contou sua história, que não pode ser resumida nos espaços deste artigo. Uma leitura aprofundada das falas trouxe, pela repetição e pela similitude de conteúdo (Bardin, 2004), que esses idosos viveram processos simultâneos de enfrentamentos de dificuldades e de afetividade num contexto de forte dominação parental sobre eles quando crianças. As pessoas idosas sofreram dificuldades ao longo da vida, mas valorizam o afeto. Vamos distinguir nas falas essa dupla dimensão do afeto e da dificuldade, conforme emergiu do corpus da pesquisa. Tomás ${ }^{1}$ (62 anos), vitimizado pelo genro, migrou do interior de São Paulo para Brasília e, quanto ao afeto e às dificuldades em sua família de origem, diz o seguinte:

Eles me respeitavam. Nós nunca brigamos, nunca troquemos tapa, nada. Em casa sempre foi assim, os irmãos sempre unidos. Unido assim, amava um ao outro. Amava, ter amor, né? O mais sacrificado dentro de casa fui eu. Era assim, né? Tava sempre ajudando dentro de casa. Meu pai foi pra segunda guerra mundial. Aí eu fiquei intermediário da minha mãe e dos meus irmãos em casa... eu não estudei quase, que eu não tive quase tempo. (Tomás, 62 anos)

Margarida, 70 anos, migrante do Maranhão, vitimizada pela nora e, antes, espancada pelo marido, diz que "hoje em dia eu vivo num apogeu", mas foi abandonada pela mãe e criada pela avó, tendo posteriormente abandonada a filha, diz:

A vida era muito difícil e eu era pequena quando eu fui abandonada pela minha mãe. Mamãe também não tem culpa, porque ela também sofreu muito. Ela foi criada sem pai e sem mãe também...

Todos os nomes são fictícios. 
Joaquim, de 70 anos, empresário, que ficou cego, migrou de Minas Gerais, é vitimizado pelo filho mais novo, relata que trabalhou na fazenda e recorda-se das dificuldades vividas, pois os irmãos eram muito novos e a mãe não tinha renda. Considera que desenvolveu uma sensibilidade maior, que o possibilita sentir os maus-tratos na pele.

A sensibilidade... é o olhar com a pele, né? É... olhar, sabe? O olhar de desprezo, olhar de distância, a coisa também rebela, né? Essas coisas...

Rute, de 80 anos, migrou do Recife. Maltratada pelo marido, e depois pelo filho, declara-se independente, e recorda sua história de vida com certa emoção, ao relatar que perdeu a mãe quando tinha apenas um ano de idade. Afirma também que a pessoa idosa pode ficar chata, o que se pode perceber no relato abaixo:

É bom, como eu disse: eles lá eu aqui. Eu não convivo com família, é família pra lá e eu pra cá. Eu não quero conviver com netas, com aquele monte de criança, não. Deus me livre e guarde! Eu construí meus filhos sozinha, só eu que gosto deles. Embora não gostem de mim... É como diz o ditado: uma mãe é para 100 filhos e 100 filhos não é para uma mãe. É porque uma mãe ama 100 filhos e 100 filhos não ama uma mãe. (Rute, 80 anos)

Carmelita, de 69 anos, migrou do Ceará, recorda as dificuldades enfrentadas com a morte do marido. Hoje é vitimizada pelo genro. Para criar seus filhos, começou a trabalhar como cozinheira e relata a opressão vivida no trabalho. A vida na família de origem se inscreve no discurso de Carmelita, como uma família idealizada e harmônica, tanto de afeto como de trabalho e dificuldades, além de presença da força da autoridade paterna que levava os filhos para trabalhar: 
Família do meu pai e minha mãe, todos os dois eram unidos. Meus irmãos... ninguém brigava um com outro, ninguém não discutia, ninguém andava batendo um no outro. Era uma família muito unida, a família do meu pai e da minha mãe. Fomos criados todos trabalhando, meu pai levava pra trabalhar. (Carmelita, 69 anos).

Ana, de 67 anos, migrou do Ceará e suas recordações estão voltadas para o trabalho na roça para ajudar na sobrevivência da família. Seu marido migrou antes, pela seca, em busca de trabalho no Rio de Janeiro. É vitimizada pelo filho.

Rita, de 79 anos, é a sexta de uma família de onze filhos, acredita ter sido discriminada pela mãe por ter o nome da avó paterna, com quem a mãe não se relacionava bem. É vitimizada pela filha mais nova, que saiu de casa por medida judicial.

Maria, de 66 anos, também fala da exploração do trabalho na infância, busca o afeto para realizar seu ideal de família feliz, unida, e esforça-se para manter a família vivendo perto dela. É vitimizada pelo neto. Foi doméstica. Foi criada sem pai e a mãe trabalhava como cozinheira. Casou-se quatro vezes, sendo que seu último casamento se desfez após 38 anos. Sua mãe trabalhava sozinha, com dificuldades, e o fato de "não ter nada" está ancorado na falta da figura paterna:

Quando eu era menina, eu fui criada sem pai. Minha mãe era sozinha... Trabalhava pra me manter, pra me dar o meu sustento, pra me dar... Eu era menina que morava no mato, minha mãe sozinha... porque eu não tive adolescência, não tive infância, não tive nada... (Maria, 66 anos).

Apesar da heterogeneidade na caracterização da família, de um modo geral, para os idosos, a família de origem² é

2 A família de origem é considerada a família nuclear de origem dos idosos. 
representada não só como um lócus de autoridade e trabalho, mas também de solidariedade, cujo objetivo era garantir a sobrevivência e a segurança material e afetiva. Assim como a casa não está separada da sociedade, os maus-tratos também não estão separados da histórias de vida em que houve violência dos maridos e autoritarismo dos pais. Seus casamentos, no entanto, foram sonhos e formas de encontrar um caminho para escapar da dominação ou para sua realização. As relações de violência, retomando nossa perspectiva teórica, estão presentes no contexto familiar e na história social de cada família em sua relação com a vida rural, o trabalho, o autoritarismo das relações paternas e conjugais.

A ancoragem da representação é feita na relação de filho com pai/mãe na família de origem. Na família construída, a relação é vista numa relação de mãe/pai/sogro/sogra com filho/filha/genro/nora, invertendo-se os papéis familiares.

\section{As representações da violência na velhice e de suas determinações}

A família construída, como vimos, estrutura-se de forma complexa, mas com expectativas de respeito e afeto. A violência na velhice não era esperada por esses idosos que a atribuem ao ambiente social desfavorável, às más companhias ou a fatores que também os vitimizam e os tornam agressivos, tais como as drogas, o desemprego, os transtornos comportamentais. Os fatores que assinalamos como doença, drogas, amizades inadequadas, condições ambientais, ancoram as representações da violência, conforme a referência a Jodelet e Moscovici.

Joaquim destaca a agressividade do agressor: 
O menino tá... o menor... tá com 20 anos, mas estamos pelejando. É agressivo. Está dando trabalho, mas está fazendo tratamento. Ele tem problema de cabeça, né? Tá fazendo tratamento, né? (Joaquim, 70 anos).

Maria ancora sua representação da violência no uso de droga:

Eu vivo bem aqui. Nós se damos muito bem. Nós somos assim... uns para os outros. Eles me ajudam, às vezes, eu ajudo eles. É assim sabe... no... no... assim, é... como fala?. No controlo a gente vive bem. Assim, não tem desentendimentos, não tem briga, não tem nada. O problema é só... só esses dois aí. O mais problemático mesmo é esse dois aí. É tudo coisa de droga, bebe e... enche a cara de droga e vem pra cá perturbar. (Maria, 66 anos).

Rita objetiva o problema no desemprego:

Ela estava desempregada, dependia da gente para tudo. Eu que agüentava as contas em casa. E ela só reclamando, também não sabia quanto custava nada. Desempregada, o tempo todo à toa. Tinha tempo para implicar. Depois que saiu daqui, arrumou emprego e tá diferente. Também agora está morando longe da gente. (Rita, 79 anos).

Carmelita faz menção da vida em comum com o agressor, ancorada em sua presença na casa, e considerada insuportável:

Hum! Quando o genro estava aqui era desaforo de briga toda hora. Era toda hora. Toda hora dava briga... (Carmelita, 69 anos)

Maria não hesita em falar da droga:

Essa coisa de andar na rua e ficar fumando essas coisa que vira a cabeça, sabe? Ele fuma e fica virado do acesso. Quando não tá com a cabeça cheia de droga, mafu né? Tá bem, acho que se não fosse essa coisa, não tinha essa agressão aqui. (Maria, 67 anos). 
As representações se objetivam e se ancoram na memória familiar, nas histórias dos sujeitos que procuram, mesmo inconscientemente, repetir vivências que valorizam, modificar padrões de comportamento que não satisfizeram suas necessidades ou elaborar vivências que ficaram presas ao passado e não puderam ser processadas.

Tanto as determinações sociais como as intersubjetivas estão presentes nas falas dos idosos como "fatores" ou causas da violência de um familiar. Essa percepção está objetivada/ ancorada com as reflexões acerca do espaço da rua, do uso de drogas, da transmissão familiar, das representações sociais da velhice, dentre outros.

Tomás menciona "o mau ambiente. Mau ambiente na rua. Porque um mau ambiente é ver que a pessoa não presta e está acompanhando quem não presta. Margarida diz que "a situação deles, de lá da rua, que trás de fora.... quando vai pra rua, enche a cara lá de droga, quando chega em casa é a família quem paga".

Tomás critica quem "bota culpa no governo", salientando a má educação na família, na outra família: "aquele que talvez ele maltrata... talvez que na outra família, talvez que aquele tinha mau procedimento naquela outra família e que está trazendo pra outra". Menciona que: "às vezes a pessoa não tem estrutura, não tem como ter uma estrutura, certo ambiente"

Margarida também fala da "outra família": é porque às vezes a pessoa viveu aquilo na família e acha que tem que viver assim. Aí vai e ensina os outros a serem assim, agressivo, violentos..." Refere-se também à falta de autoridade: por exemplo, você só fala, eu vou pegar uma arma aqui vou dar um tiro num... E se seus filhos vir, eles vão se criando com aquilo. Não é? Eles vão se criando com aquilo na cabeça. Então de violência se gera violência. Já vem assim da criação". 
Essas afirmações dos idosos corroboram as reflexões de Tortosa (2005, p. 45) sobre a teoria da aprendizagem social, segundo a qual as experiências vividas em família podem ser aprendidas e incorporadas ao repertório do sujeito e, posteriormente, serão repetidas como um padrão de comportamento. Marmolejo (2005, p. 82) e Tortosa (2005, p. 45) afirmam que o postulado da transmissão intergeracional dos maus-tratos preconiza que os sujeitos que viveram situações de maus-tratos quando crianças podem se tornar adultos que praticam maus-tratos.

Alguns idosos relacionam a violência com a desigualdade social, a pobreza, as más condições de vida, como Margarida, que destaca a orientação dada aos filhos e relaciona, como forma de objetivação, a violência com a perda de valores de respeito na sociedade atual:

Eu acho que é a falta de estrutura, orientação, orientação, foi falta de amor, falta de poder econômico... Muitas vezes a pessoa vive em situação de fome, de dificuldade. Aí, acha que aquele idoso está atrapalhando mais ainda, aí começa a ficar nervoso e desconta naquele idoso. [...] Parece que pras pessoas de hoje, ele não entende mais assim o sentido dessa vida de hoje, dos procedimentos atuais. Não respeita mais pai nem mãe. Antes, fumar na frente de pai e mãe era um escândalo; agora, [se] faz tudo.

Na percepção dos entrevistados, o uso de drogas lícitas e ilícitas é outro fator para a ocorrência dos maus-tratos contra os idosos na família, concordando com os dados da literatura. Segundo Tortosa (2005, p. 46), os sujeitos consumidores de drogas estão predispostos a vitimizarem seus familiares com mais freqüência do que aqueles que não utilizam drogas, o que pode ser corroborado pela fala de alguns sujeitos.

Alguns idosos ancoram a representação no uso de drogas, que torna os jovens como "bichos": 
É droga, essas coisas, problemas de drogas. Coisa do mundo. Aí eles entram em casa feito bicho. E os pais que pagam a situação deles, de lá da rua, que trás de fora... Se a pessoa não bebesse, era maravilhoso. Mas quando entra a bebida e entra a droga, pronto, acabou o sossego. (Maria, 66 anos)

[...] levam a isso e até matam também. O bicho drogado, drogado, drogado... (Carmelita, 69 anos)

[...] é usar as drogas. Ele usava drogas aqui em casa. Oferecia pros filhos. (Tomás, 62 anos)

É bebida, é droga, más companhias... (Joaquim, )

Rute menciona tanto a bebida como a falta de amor:

Acho que tem muita coisa, sabe, desde bebida, drogas, falta de amor. "Ichi" tem muita coisa. Eu acho que a bebida também ajuda sabe! Esse aí quando bebe fica ruim. Fala bobagens para mim. (Rute, 80 anos)

Alguns representam a violência objetivada na falta de religiosidade ou na tentação do diabo como determinantes da violência. Rita destaca: "falta de temor a Deus" e Carmelita assim se expressa:

Tentação do cão, mulher! Tentação do diabo, porque Deus não permite isso pra ninguém. Vou te falar uma coisa, Deus quer o filhos dele. É o coração bom, é divino com Deus, pedindo a Deus a felicidade, a saúde. Mais uma coisa dessas que é mandada pelo diabo pra matar, não é de Deus não. (Carmelita, 69)

Margarida também destaca: "uma pessoa que não tem Deus, que é capaz de maltratar um idoso?! Falta temor a Deus. Essas coisas. A pessoa que tem temor a Deus e é humano não vai maltratar um idoso". Outros, como Tomás, falam de "índole... eu acho porque a pessoa é mais a parte espiritual. Assim fala Rita: "a pessoa parece que fica com um karma, um espírito, não sei dizer bem, assim, de mal”. 
As representações sociais da velhice, presentes no imaginário social, também podem contribuir para potencializar os maus tratos, à medida que, para os sujeitos da pesquisa, o olhar da família e da sociedade com relação à velhice é negativo e estigmatizador:

[...] porque a gente está velho, eles encostam lá pro canto. Tem filhos que bota até os pais no asilo, pra ficar sossegado, pra não ter trabalho com os pais, com a mãe. Sei lá... (Maria, 67 anos )

[...] pessoa do idoso precisa carinho também né? Se a pessoa não gosta do idoso não dá carinho, você não acha? (Ana, 66 anos)

[...] muito triste ficar velho e não ter a atenção da família. (Rute, 80 anos).

Há a percepção do desejo de que os idosos morram:

Acha que o idoso não presta mais, não serve mais para nada, já está na hora de morrer. (Rute, 80 anos)

Faleiros (2007), como vimos, trata da violência na relação de poder e Corsi (1994, p. 23) refere-se ao comparecimento da violência mediante um desequilíbrio de poder. Para o autor, é suficiente que um sujeito acredite no poder e na força do outro para que se produza o desequilíbrio, mesmo que não tenham existência no real. Isso se verifica na relação de perda de poder que os idosos estabelecem no contato com os outros membros da família:

O idoso é mais fraco e não tem força para devolver os maus tratos. (Rute, 80 anos).

[...] já que é o idoso que tem menos... ação... não tem mais voz ativa. Sabe que ele não tem mais vigor para nada. Depende tudo da consciência daqueles. (Margarida, 70 anos) 
Outro aspecto das representações sociais da velhice que potencializa os maus-tratos está objetivado na incapacidade de lidar com o processo de envelhecimento por parte dos familiares e da sociedade, conforme relatos a seguir:

Aí eles acham assim: velho tem ficar no canto, dormir, tomar remédio pra dormir. Tomar remédio pra dormir, ficar o dia inteiro dormindo, sem comer nada. Para não dar trabalho. (Maria, 69 anos)

Acho que o velho fica com manias e chato e tem gente que não quer saber e perde a paciência, sabe? A pessoa fica nervosa por causa... porque... o idoso, quando ele fica mais velho, ele fica mais chato, a pessoa mais nhem, nhem, nhem, mais chato, então as pessoas não têm paciência. É falta de paciência. (Rute, 80 anos)

As dificuldades socioeconômicas também comparecem como potencializadores dos maus-tratos. A dificuldade em satisfazer as necessidades básicas de sobrevivências como a alimentação, por exemplo, faz com que o idoso seja visto como um a mais no grupo familiar para dividir os escassos recursos, o que faz dele o bode expiatório familiar.

Muitas vezes a pessoa vive em situação de fome, de dificuldade. Aí acha que aquele idoso está atrapalhando mais ainda, aí começa a ficar nervoso e desconta naquele idoso. (Margarida, 70 anos).

A possibilidade de ouvir os idosos sobre essas determinações dos maus-tratos demonstrou que, para o grupo, são múltiplos os fatores que potencializam os maus-tratos intrafamiliares.

Pode-se perceber que os idosos compartilham modelos de pensamento e de explicações para os fatores de risco de maus-tratos que se ancoram na vivência cotidiana da velhice. Como sujeitos ativos no processo de construção da realidade (sábios pensadores), apropriam-se das informações 
disponíveis e acessíveis sobre tais fatores de risco presentes no mundo social, para então compreendê-los com base em suas experiências e, assim, posicionar-se e agir com relação a elas.

Os idosos ancoraram os fatores de risco para os maustratos no uso de drogas lícitas e ilícitas, na desestrutura familiar, na rua como o meio de potencializar os maus-tratos, na falta de religiosidade, assim como também na transmissão familiar e nas representações sociais da velhice. Para aprofundar essa percepção da vivência da violência, nossa pesquisa perguntou aos idosos o significado mais importante dos maus-tratos contra os velhos.

\section{A representação da violência no cotidiano e nas relações}

Conforme a conceituação de representação social acima explicitada, a análise da dialética da violência feita por Faleiros (2007) e a proposta de análise de conteúdo de Bardin (2004), vamos evidenciar o significado de maus-tratos para os idosos, utilizando a tipificação que surgiu das falas nas entrevistas. Para os colaboradores da pesquisa, os maus-tratos são representados e ancorados em "faltas" e "negações". É freqüente a referência aos maus-tratos como "falta" tanto na dimensão emocional como material. Assim, foi considerada, de forma intensa, a objetivação na falta de compreensão, na falta de amor, na falta de respeito, dentre outras. A violência é socialmente representada no processo de comunicação social, como uma falta, em duplo sentido: a falta que alguém comete e a falta de um direito que alguém merece. A falta de respeito aparece nas falas de Tomás, Rita, Joaquim, Ana e Maria. Assim fala Tomás: 
Maus-tratos é falta de respeito. E não ter consideração pelo velho, ser moleque... quem só anda com palavrão na boca é moleque. E não ter consideração pelo velho. É falta de respeito. (Tomás, 63 anos).

Os idosos mencionam sofrer todos os tipos de violência ${ }^{3}$ e os objetivam em atos concretos de fala, de negligência, de agressão física. Assim a agressão verbal está ancorada no "xingar", como diz Carmelita: "Ele mandar eu tomar não sei aonde". Rita faz referência à discriminação: "ela com aquela falação, por causa de comida, por causa de tudo. Com a comida era melhor para elas. Aí estava com muita discriminação com a gente".

Tomás objetiva a violência física, na negação do sujeito: "ele me batia aqui dentro de casa. Ele me espancava aqui dentro". Maria fala da discriminação social, objetivada no desprezo, como negação do outro:

[...] o desprezo também! Depois que fica velho, não passeia com a gente, não sai assim pra divertir, pra levar pra algum lugar, assim um lazer, pra gente se envolver com eles, né. Não! Eles acham que a gente tem que ficar em casa, ficar fazendo crochê... Nem crochê eu sei fazer! (rindo) Fazer crochê, eu não sei fazer crochê. (Maria, 66 anos)

Três idosos assinalam a negligência, expressando a negação do cuidado, como na definição que Faleiros (2007) faz da violência:

Fiquei doente tive de buscar uma pessoa pra cuidar de mim... passo mal, a minha amiga é que cuida. E eu não tenho coragem de pedir, de falar. Acho que eles que tinham de vê que mãe precisa, né? (Margarida, 70 anos)

3 Para definições dos tipos de violência, ver Faleiros (2007). 
Eu acho que é isso de ver a gente necessitando e não dá a mínima pra gente. Você sabe, eu tô com... assim, né... a vista. E não ajuda, só com o dinheiro. (Joaquim, 70 anos)

Tive que fazer ponte safena, muitas e foi uma coisa sozinha, ela morando aqui e eu assim... o meu filho de Minas queria vir, mas é desaforo ela aqui, morando, comendo e na hora de ajudar nada... eu passei foi muita solidão, sentia muito sozinha. (Rute, 80 anos)

Carmelita objetiva a representação da violência financeira em relação a seu marido no "pegar dinheiro":

Pegava o dinheirinho dele lá no centro, ele mentia para o pobre do velho: "Ah, seu Otávio eu estou devendo não sei quanto ali na borracharia, não tenho dinheiro pra pagar..." (Carmelita, 69 anos)

A violência é objetivada também em ameaças à vida da pessoa idosa, como diz Maria ao se referir ao neto e ancorada na representação do fogo:

Pegou o litro de óleo lá dentro derramou aqui em cima do sofá, derramou aqui no chão, foi um peteco! Ele queria tocar fogo. $E$ aqui é assim qualquer coisa eu escondo as facas, escondo tudo. (Maria, 66 anos)

Pode-se verificar que a objetivação/ancoragem das representações se faz com base na rede de significados desses sujeitos. Nessa perspectiva, foram considerados como maus-tratos o bater, xingar, ofender, maldade, deixar a pessoa de lado sozinha, desprezo, palavrões e outros. Outras ancoragens realizadas dizem respeito às faltas e negações, tais como falta de compreensão, falta de atenção, falta de respeito e outros. No entanto, cada idoso relata o mau-trato de forma diferente, conforme sua subjetividade. Tomás relata sua experiência de maus-tratos em várias situações que envolviam 
desde ofensas a ameaças de morte, e ainda era constrangido a silenciar.

A representação da velhice como um tempo de tranqüilidade foi perturbada pelas violências. Os idosos demonstram, em consenso, sua indignação com relação a essa vivência, o que pode ser considerado um dado importante para a procura de soluções para a situação vivida. Para os idosos, a velhice seria um tempo de viver tranqüilo, sossegado, com amor e compreensão da família. A família aparece, retomando Rudinesco, reinventada pelo medo como veremos a seguir nos relatos dos idosos:

A gente na velhice quer viver em paz de Deus, como família. Depois de tudo na vida... viver xingamento, briga dentro de casa... (Carmelita, 69 anos).

Margarida refere-se aos maus-tratos que viveu durante dez anos. Durante esse tempo sentiu-se impossibilitada emocionalmente de denunciar os vitimizadores. Para ela, a vivência de maus-tratos poderia tê-la levado à loucura ou mesmo à morte:

A nora me maltratava. Foi dez anos de agonia. Ela de mal comigo, dez anos na minha casa, apesar de que eu sustentava todo mundo.. chegou a bater na minha cara. Me insultava, ai, aquela coisa dentro de casa sem falar comigo. Quase fui pro hospício. Pensava: ou o hospício ou o cemitério. (Margarida, 70 anos)

Carmelita refere-se à experiência de maus-tratos, que a também perdurou por dez anos e obrigou-a a abandonar sua casa para evitar que o genro cumprisse suas ameaças de morte. Para ela, a vivência de maus-tratos foi significada como "minha vida acabou":

Ele quis matar a gente aqui. A gente precisou dormir uma noite naquele hotel ali da frente e pegar ônibus para ir para casa da minha nora e dormir lá, porque ele queria matar todo mundo. Aí 
nós fomos parar no Goiás. Ficamos lá no Goiás. Aí minha vida acabou. (Carmelita, 69 anos)

Faleiros $(2004$, p.13) refere-se à violência contra o idoso implicada na ruptura do pacto de confiança e também na negação desse sujeito em seus direitos e em suas necessidades. A vivência de maus-tratos expõe a ruptura desse pacto de confiança que se estabelece implicitamente e, ao ser quebrado, remete a sentimentos de desamparo e decepção. $O$ impacto subjetivo da violência se manifesta no sofrimento.

\section{A representação do sofrimento e do monstro}

Como menciona Faleiros (2007), além do prejuízo e do dano, a violência provoca sofrimento que pode afetar a auto-imagem da vítima, trazer depressão ou mesmo paralisar o sujeito, fazendo-o chegar no seu limite de dor. Rita fez a denúncia porque "não agüentava mais", mas "sofri muito, ela estava desempregada, a gente pensa em tudo". Rita, como vimos sofre com a solidão: "eu passo é muita solidão, sentindo muito sozinha".

Já Ana, durante todos os encontros referiu-se aos maus-tratos com distanciamento, provavelmente como um mecanismo de defesa para evitar assumir a situação vivida. Esse mecanismo utilizado por Ana pode ser compreendido a partir da perspectiva da zona muda 4 das representações sociais, como espaços de representações que embora sejam comuns a um grupo especifico, e por eles sejam compartilhadas, não são revelados facilmente nos discursos dos sujeitos no cotidiano e menos ainda nos instrumentos de pesquisa, já que são conflitivos com as normas e valores morais (Menin, 2006). Ela

${ }^{4}$ Expressão utilizada por Jean-Claude Abric (2003). 
diz: "... vai e fala uma coisa que você não gosta. Tem gente que fica magoada de dizer uma direta..."

Joaquim, também preferiria não falar do assunto, pois é muito doído, objetivando a dor:

Ah, não gostaria de falar, não. Acho difícil falar disso. Foi muito doído. Peleja com filho pra passar por isso. Entendeu? Não gostaria tocar nesse... assunto, sabe? Acho que dei tudo do melhor e a gente pensa que errou, não devia dar tudo, né? (Joaquim, 70 anos).

Rita fala claramente que sentiu angústia, um aperto no peito:

Depois senti angústia, sabe? Um aperto no peito, estou tratando a depressão. Sinto falta da minha neta. Ela não deixa ela vir aqui. Eu criei a menina, sou apegada a ela e agora ela não deixa... (Rita, 79 anos).

As conseqüências dos maus-tratos vividos para os sujeitos são objetivadas na ordem física, econômica e emocional, mas, de maneira geral, os idosos referem-se às marcas emocionais deixadas por eles. Dentre essas, estão a necessidade de abandonar a casa, a depressão, o isolamento e a separação de familiares queridos:

Quando chegamos aqui ele tinha quebrado os vidros da porta. Arrancou a fechadura e enfiou um ferro lá outro aqui, arrancou os negócios da luz, aquela tampa que tem. Quebrou as telhas da casa todinha. Quando nós chegamos aqui, meu velho foi fazer o piso lá em cima, piso de cimento, por causa da água que encharcou em cima e soltou tudo desse jeito. Foi um sofrimento. Eu dormia lá no chão em Goiás e preocupada aqui. Quando chegamos aqui, só tinha dívida, telefone cortado, a luz cortada, a água cortada. [...] Eu fiquei bastante preocupada, pensa se eu durmo de noite aqui? E remédio controlado para esse sentimento... (Carmelita, 69 anos). 
Eu passei depressão um tempo, fiz tratamento, agora não passa. Fica um nó. (Joaquim, 70 anos).

Conforme Sommerhalder e Nogueira (2000), as relações entre gerações mudam com a cultura, as transformações sociais, o ciclo das famílias, as condições e o papel da mulher. Mudam também, conforme constatamos, com a violência e trazendo conseqüências para os avós quando da perda parcial ou total do contato com os netos, o que gerou intenso sofrimento, queda na qualidade de vida e na saúde física e emocional, conforme Margarida:

Eu não podia ver a menina, sofria por causa dessa menina, ela não me deixava ver a menina. A bichinha chorava pra vir pra cá, ela também não deixava. Maltratava, até pra pirraçar a gente. $E$ eu sofria dia e noite, pedindo a Deus pra resolver esse problema dela deixar a criança vir aqui. (Margarida, 70 anos).

Segundo os entrevistados, eles fizeram o possível para o bom entendimento, como diz Carmelita: "ele comia de tudo e nunca sovinei nada dele". Segundo Margarida: "tiveram tudo na mão, tiveram amor, tiveram carinho, tiveram tudo e se tornam um bando de monstro." Para Rita: "estraga uma coisa, eu que tenho que ir atrás. Depois que arrumava, ela punha defeito." Rute diz: "às vezes os pais dão tudo e no final ganham isso. Às vezes a pessoa não tem nada de bom para dar e tem raiva do mundo e desconta no velho que dá perto dele."

Dada a forte mobilização emocional vivida pela experiência de maus-tratos, os idosos atribuem aos vitimizadores características não humanas para assim poderem nomear e explicar a experiência vivida. $O$ vitimizador é representado como monstro, objetivado no marimbondo, e também como um "karma".

É igual monstro dentro de casa. É tentação do cão, mulher. Tentação do diabo. Porque Deus não permite isso pra ninguém. (Carmelita, 69 anos) 
Acho que só um monstro pode maltratar os pais. Não têm nada de ser humano... Tiveram tudo e se tornam um bando de monstro... mas acho que todos se juntam ali e cai tudo igual marimbondo em cima de um só. (Margarida, 70 anos)

[...] a pessoa parece que fica com um karma, um espírito, não sei dizer bem, assim, de mal. (Rita, 79 anos)

É possível verificar que as representações sociais que os idosos construíram dos vitimizadores estão objetivadas nos sentimentos de ingratidão, egoísmo e hostilidade, sendo caracterizados pelas vítimas como não-humanos.

\section{Ação frente à representação: atitudes frente aos maus- tratos}

Frente à violência sofrida, os idosos têm medo de falar ou sofrem com isso, formando-se o que Faleiros (2007) chama de conluio do silêncio, que objetiva manter o pacto de confiança pressuposto pelos laços familiares:

E eu não tenho coragem de falar, de reclamar. De reclamar ajuda.

Eu acho que eu tenho medo da pessoa ficar ofendida. Se eu pensar que a pessoa visse pra mim seria melhor. Sem precisar falar nada. (Maria, 67 anos)

Pode-se perceber uma ancoragem da representação do silêncio na visão compartilhada de que a família deva ser um local de união e solidariedade, de confiança e de afeto, apesar dos conflitos que ela venha a vivenciar. A manutenção do ideal de família supõe o mito do amor dos pais pelos filhos e dos filhos pelos pais.

Para os idosos, a decisão de desvelar a situação de maus-tratos vividos na família não é fácil, mobiliza sentimentos na medida em que remete à imagem de família internalizada, aos papéis desempenhados e ao lugar atribuído a eles na 
família. Mesmo nesse grupo de idosos que já tem revelada a violência dentro de casa - não é o caso da maioria - há distintas posições:

Às vezes, a gente pensa que não tem o que fazer ... que tem que levar a vida com isso, mas tem que ir atrás da justiça pra dar jeito. Eu liguei lá no SOS... Não foi fácil... (Rita, 79 anos)

O idoso tem que agir, senão fica na mão desses. Não dá na velhice ter que aturar... (Rute, 80 anos)

As pessoas têm medo, né? Mas tem que ir nos lugares pedir para tirar a pessoas que não sabe conviver... (Carmelita, 69 anos)

A pessoa tem que tomar uma providência na justiça. Pra pessoa ser chamada atenção lá, né? Perante a lei. Pra ser chamado lá, na responsabilidade. (Tomás, 63 anos)

As estratégias de enfrentamento da violência são referenciadas de forma diversificada. Para Carmelita é preciso denunciar e tirar o agressor de dentro de casa: "é a gente denunciar e tirar ele de dentro de casa, como eu fiz, moça". Ana diz que alguém precisa defender o idoso, principalmente se for dependente: "os outros é que tem que fazer por ele. Só se for um idoso ainda bem lúcido, ainda que ele saiba, né?. Mas um, assim, que depende tudo dos outros, ele não sabe se defender, ele não pode se defender se não tiver outro que venha dali, que vê como tão tratando aquele, né”. Joaquim lembra da religião, da solução caseira e da ajuda: Diz Joaquim: "acho que Deus guia a gente, né? Acho que tem que tentar em casa, resolver, né... Quando não dá tem que pedir ajuda, entendeu?"

Margarida está descrente do poder familiar e menciona a responsabilidade:

Eu acredito que quase nada, porque eles não ouvem, dá conselhos eles não querem escutar e agir também com ação eles não tem 
força. Para denunciar, também não tem coragem, aí fica sendo só vítima toda a vida. Eu acho que depende só deles mesmo serem esclarecidos de outras fontes, porque o partido do idoso a gente quase não tem saída. (Margarida, 70 anos)

Maria chama a atenção para o diálogo e a ação do governo na prevenção da violência: "dialogar... Eu acho que o governo deveria investir mais neste sentido. Na prevenção!" Já Ana menciona o "deixar prá lá, porque filho é sangue", mas o idoso tem medo do agressor:

[...] que é filho, e sangue, né? Eu penso que tem medo do filho ficar chateado com a mãe, com o pai. Prefere deixar pra lá, né? Às vezes pensa que o filho é que tem que ver que os pais tão velhinho e não pode ser maltratado. Não tem força, é fraquinho igual criança. (Ana, 66 anos)

Rita diz que a religião não adiantou e menciona a responsabilidade:

Só se for religião, mais aqui não adiantou não. Temor a Deus. Saber que a gente é responsável por tudo que a gente faz e fala. (Rita, 79 anos)

A fala dos idosos sobre a dificuldade de revelar os maus-tratos confirma os estudos de Minayo (2003) e Faleiros (2007), visto que a impossibilidade de falar dos maus-tratos está implicada no constrangimento ou no temor a punições e retaliações de seus agressores. Para os entrevistados, a denúncia só foi feita quando a questão já havia chegado ao seu limite de tolerância, quando falta diálogo e os idosos estão muito machucados:

Então eles me machucam muito em palavras. Porque bater, espancar ou coisa assim, não é só o físico. Palavra também mata. Que eu fico aborrecida, fico chateada, fico magoada, ressentida, isso me maltrata também por dentro. [...] Se tivesse respeito, eles tinham mais diálogo, mais paciência comigo e me entendia, 
o meu problema [...] não tava mais disposta agüentar, nem achei que eles iam vir. Velho é sempre deixado de lado mesmo. (Maria, 66 anos)

Tomás diz que não podia ficar quieto diante da ameaça de morte e o agressor não podia ficar impune: "foi eu que fiz. Porque não podia ficar impune... eu tinha que fazer mesmo a denúncia. Eu não posso ficar quieto, com umas coisas dessas. Era ameaça toda hora. Ele falou que ia matar nós”. Rita diz que a violência estava intolerável, mas não foi fácil:

Liguei! Estava intolerável. Foi fácil não! Foi a raiva daquele dia mesmo, que eu acabei fazendo isso.. Mas eu me senti muito mal. Mas eu acho que não tinha outro jeito.. Tem uma hora que transborda. Mas é muito ruim fica uma coisa ruim. Tirar a filha de dentro de casa. (Rita, 79 anos).

Carmelita diz que foi ao Fórum contar o que estava passando: "Denunciei duas vezes. A última vez eu fui no Fórum, sabe? Contar lá pro advogado o que estava se passando." E Joaquim diz que "eu tomei atitude" que a mãe não toma, pois "ela prefere defender o filho e deixar o marido de fora" para não deixar o filho apenado, mas

[...] tem as autoridades, evidentemente, entendeu, que eles têm poder... e se o pai tomar uma atitude dessa é porque não quer que repita de novo... É por que... se ele tomou uma atitude dessa, é porque chegou ao extremo. É que perdeu todas as forças, a autoridade perante aquele filho, né? (Joaquim, 70 anos)

Fazer a denúncia traz sofrimento e exige coragem para tirar o agressor de dentro de casa e não desistir da denúncia no enfrentamento com a polícia:

Eu não tinha coragem de tirar ela de dentro de casa. (Margarida, 70 anos)

Eu cheguei a fazer denúncia e desisti de resolver. Eu não tenho coragem, acho que tem que resolver fora disso, ficar levando a gente na delegacia para ver isso. (Maria, 66 anos) 
É difícil falar de filho pros outros. Ah, acho que é que os pais amam seus filhos e é difícil chegar e ficar falando deles pros outros. $O$ filho pode ficar chateado. Acha que o pai e a mãe tão jogando charadinha para ele. (Ana, 67 anos)

A denúncia não foi pacificamente aceita pela vizinhança, como diz Tomás, inclusive pelo medo que o agressor impõe: "a vizinhança tudo se revoltou. Tudo tinha medo dele também. Ligaram lá no lugar do idoso pra ajudar a gente, né?"Por outro lado, a vizinhança também denuncia, como diz Margarida: "não chamei ninguém, mas veio... Fiquei sabendo depois que minha vizinha é que fez..."Houve denúncia da vizinhança no caso de Maria: fizeram uma denúncia anônima. Mas eu sei que foi os vizinhos e penso que meus filhos também. Querendo resolver a coisa no modo deles. Os vizinhos viam a bagunça aqui, né?"

Os mecanismos para lidar com a vivência de maus-tratos se apresentam em duas vertentes, embora a primeira seja limitada: a dos idosos que denunciam e a dos que optam por silenciar por diversos motivos, dentre os quais para preservar a família, proteger os filhos e familiares. Para os idosos, são muitas as razões para silenciar os maus-tratos intrafamiliares. O silêncio é ancorado no amor pelos filhos, na culpa e na vergonha, que são algumas das "justificativas" para que o idoso vitimizado não procure ajuda e também no medo de ser ainda mais maltratado:

É receber mais maus-tratos... Porque uma pessoa de idade não vai enfrentar uma pessoa nova, que tem saúde. (Tomás, 62 anos)

Acontece é porque tem medo de chegar na delegacia e denunciar, com medo de quando chegar de lá, já até matar a pessoa. É. Ter mais violência... a polícia dá um bocado de carão na cara do cara... E o cara vai, fuma maconha e mistura com a bebida e quando chega agora "ah, vai me pagar. (Carmelita, 69 anos) 
É pro velhos ficar encubado... Amordaça a pessoa, que é pra pessoa de idade ficar calada, ficar com medo, né? Porque eu faço isso, faço aquilo, mato e não sei o quê, né? (Tomás, 62 anos).

Acho que tem medo de ser judiado mais ainda, né? Aí o idoso fica quieto no canto dele... (Margarida, 70 anos)

Tem medo do filho ficar chateado com a mãe, com o pai. Prefere deixar pra lá, né? Às vezes pensa que o filho é que tem que ver que os pais tão velhinho e não pode ser maltratado. Não tem força, é fraquinho igual criança. (Ana, 67 anos)

Ele tem medo demais... Ele tem medo demais... Você tomar aquela atitude, e vim tudo contra eles. Tudo! No meu caso, não. Eu tomei porque tenho minha consciência tranqüila, sei o que... que eu... né? O importante é a pessoa ter consciência tranqüila. Igual eu falei, se fez alguma coisa errada, se errou... Mas não foi com maldade, com premeditação. Foi por ignorância. (Joaquim, 70 anos)

Para alguns entrevistados, o silêncio frente aos maustratos está amalgamado a valores internalizados pelos idosos, tais como a função dos pais, dos laços familiares consangüíneos, do medo de retaliação, falta de recursos internos, a procura de evitar a culpa dentre outros.

\section{Considerações finais}

A análise do corpus da pesquisa possibilitou avançar no deciframento da violência intrafamiliar contra a pessoa idosa. As representações descortinadas puderam ser articuladas ao contexto social, à história sociofamiliar e ao sofrimento das pessoas. A violência intrafamiliar não está separada da violência social, pois implica relações complexas e diversas com os processos e a estrutura social do desemprego, do crime, do uso de drogas. Além disso, as relações imediatas não se restringem aos mais próximos, mas aos vizinhos e 
aos serviços de proteção. É fundamental para a revelação, para o rompimento do silêncio, que esses serviços funcionem adequadamente.

As representações sociais dos maus-tratos na família estão objetivadas tanto na visão dominante de família como um lócus de união e de reciprocidade e, ainda, no contexto de violência da sociedade. Mas quando a relação de violência torna-se insuportável e transborda os limites da tolerância, como a ameaça de morte, é preciso que o "monstro" ou o "mal" seja extirpado com a denúncia, com a saída do agressor de dentro de casa ou com a mediação externa do conflito. A objetivação da representação da violência é relacional, conforme a articulação da teoria das representações e da violência acima expostas.

As faces da violência de prejuízo, danos, sofrimento e medo (Faleiros, 2007) foram desveladas, mostrando que as pessoas idosas buscam enfrentar o "doído" e o "difícil" de denunciar o filho por diferentes formas, como calar-se, denunciar, buscar tratamento para o agressor, dialogar, brigar.

Enfim, a violência intrafamiliar é uma das questões mais complexas no enfrentamento da violência, pois envolve "o sangue do sangue", o pacto de confiança, as histórias familiares e as relações sociais mais complexas e profundas.

\section{Referências}

ABRIC, Jean-Claude A zona muda das representações sociais e seu papel nas práticas sociais. Conferência apresentada na III Jornada Internacional e I Conferência sobre Representações Sociais no Rio de Janeiro, Brasil, em setembro de 2003.

ARENDT, Hannah. Da violência. Brasília: EDUnB,1985. 
BARDIN, Laurence. Análise de conteúdo. 3. ed. Lisboa: Edições 70, 2004.

BAUER, M W. Análise de conteúdo clássica: uma revisão. In: BAUER, M. W; GASKELL G. Pesquisa qualitativa com texto, imagem e som: um anual prático. 4. ed. Rio de Janeiro: Vozes, 2005.

BRAUD, Philippe. Violences politiques. Paris: Inédit, 2004.

CORSI, J. Violencia familiar: una mirada interdisciplinar sobre un grave problema social. 5. ed. Argentina: Paidós, 2004.

FALEIROS, Vicente de Paula. Violência contra a pessoa idosa: ocorrências, vítimas e agressores. Brasília. DF: Universa, 2007.

. Cidadania: os idosos e a garantia de seus direitos. In: NERI, A. L. (Org.). Idosos no Brasil: vivências e desafios e expectativas na terceira idade. São Paulo: FSP/SESC, 2007b.

. Violência na velhice. O Social em Questão, Rio de Janeiro, v. 8, n. 11, p. 7-30, 2004.

FINKELHOR, D.; GELLES, R. J.; HOTALING, G.; STRAUS, M. A. The dark side of families: currrent families violence research. Beverly Hills, 1993.

FOUCAULT, Michel. Microfísica do poder. Rio de Janeiro: Graal, 1979.

INSTITUTO BRASILEIRO DE GEOGRAFIA E ESTATÍSTICA (IBGE). Censo demográfico 2000. Rio de Janeiro: IBGE, 2001.

JODELET, D. Representações sociais: um domínio em expansão. In: JODELET, D. (Org.). As representações sociais. Tradução Lilian Ulup. Rio de Janeiro: EDUERJ, 2001.

MARMOLEJO, I. I. Violência contra personas mayores. Barcelona: Ariel, 2005.

MENIN, M. S de S. Representação social e estereótipo: a zona muda das representações sociais. Revista Psicologia: Teoria e Pesquisa, Brasília, v. 22, n. 1, jan./abril, 2006.

MERTON, Robert K. Sociologia: teoria e estrutura. São Paulo: Mestre Jou, 1970.

MINAYO, M. C. Violência contra idosos. Cadernos de Saúde Pública, v. 19, n. 3, p. 783-791, maio/jun. 2003. 
MOSCOVICI, S. A representação social da Psicanálise. Rio de Janeiro: Zahar, 1961.

OSÓRIO, L, C. Família hoje. Porto Alegre: Artes Médicas, 1996.

RUDINESCO, E. A família em desordem.Trad. André Telles. Rio de Janeiro: Jorge Zahar, 2003.

SARTI, C. Famílias enredadas. In: ACOSTA, A. R; VITALE, M. A. F. (Org.). Família, redes, laços e políticas públicas. São Paulo: IEE, PUCSP, 2003.

SINGLY, François. Sociologia da família contemporânea. Rio de Janeiro: FGV, 2007.

SOMMERHALDER, C.; NOGUEIRA, E. J. As relações entre gerações. In: NERI, A. L.; FREIRE, S. A. (Org.). E por falar em boa velhice. 2. ed. Campinas: Papirus, 2000.

SPERBER,Dan. O estudo antropológico das representações; problemas e perspectivas. In: JODELET, D. (Org.). As representações sociais. Tradução Lilian Ulup. Rio de Janeiro: EDUERJ, 2001. p. 91-103.

TORTOSA, Juan Munoz. Personas mayores y malos tratos. Madrid: Pirámide, 2004. 